\title{
Knowledge about glaucoma and epidemiological profile of subjects seen in a campaign conducted at the University Hospital Lauro Wanderley
}

\author{
Conhecimento da população sobre glaucoma e perfil \\ epidemiológico em campanha realizada \\ no Hospital Universitário Lauro Wanderley
}

Carla Christina de Lima Pereira ${ }^{1}$, Gabriella Alves de Lima Félix ${ }^{1}$, Iwaniec Eugênio Albuquerque Moura ${ }^{1}$, Jamili Anbar Torquato², Marielle de Medeiros Rodrigues Guedes ${ }^{1}$

\begin{abstract}
Objective: To evaluate the level of knowledge about glaucoma in a population randomly selected, so as to correlate with epidemiological and socio-cultural. Methods: We conducted a transversal analytical study by means of questionnaires containing general questions about glaucoma, patients participating in a campaign for awareness and prevention of glaucoma. Results: Of 200 respondents, $54.5 \%$ were female and $45.5 \%$ male, mean age 51 years and 11 months. Regarding race, $54 \%$ are brown, $29 \%$ white and $17 \%$ were black. $85 \%$ reporting having eye exam at another time. With respect to education, $5 \%$ never attended school, $22.5 \%$ had studied the first to fourth grade, $15 \%$ of 5 th to 8 th grade, $45 \%$ had completed high school and $14.5 \%$ higher. When asked, only $32 \%$ (64) of patients reported knowing the disease and of these $71.87 \%$ (46) claimed to be a pathology that glaucoma has no cure, but control and $48.4 \%$ (31) had glaucoma cases in the family. With regard to treatment, among those who knew the disease, $64 \%$ (41) patients say how it comes, saying it drops the main form of treatment. Data analysis also concluded that the group of high school education had the highest proportion of respondents who said they knew glaucoma, accounting for $69 \%$ of these. Conclusion: Corroborating these factors, which consist of barriers to diagnosis and fidelity to treatment, this study examined the actual existence of misinformation from the public about glaucoma, its complications, treatment and methods for diagnosis. The available literature found that patients with less education were more about the ignorance of his condition, this information was also verified in this study. Proved insufficient knowledge about glaucoma, the forms of prevention and treatment. This suggests the need for educational activities aimed at disseminating knowledge of glaucoma among patients and the general population, as a way to prevent vision loss.

Keywords: Glaucoma/epidemiology; Knowledge; Health promotion
\end{abstract}

\section{RESUMO}

Objetivo: Avaliar o nível de conhecimento sobre glaucoma numa população aleatoriamente selecionada, assim como correlacionar com dados epidemiológicos e sócio-culturais. Material e Métodos: Foi realizado um estudo transversal analítico, por meio da aplicação de questionários, contendo perguntas gerais sobre glaucoma, a pacientes participantes de uma campanha para esclarecimento e prevenção de glaucoma. Resultados: Dos 200 entrevistados, 54,5\% eram do sexo feminino e 45,5\% do sexo masculino, com média de idade 51 anos e 11 meses. No tocante à raça, $54 \%$ são pardos, $29 \%$ brancos e $17 \%$ negros. $85 \%$ referiram já ter feito exame oftalmológico em outra ocasião. Com relação a escolaridade, $5 \%$ nunca estudaram, $22,5 \%$ estudaram da $1^{a}$ a $4^{a}$ série, $15 \%$ da $5^{a}$ a $8^{a}$ série, $45 \%$ tinham ensino médio e 14,5\% ensino superior. Quando interrogados, apenas 32\%(64)dos pacientes relataram conhecer a doença e destes $71,87 \%(46)$ afirmaram ser o glaucoma uma patologia que não tem cura, mas sim controle e 48,4\%(31) possuíam casos de glaucoma na família. Com relação ao tratamento,entre os que conheciam a doença, 64\%(41) pacientes dizem saber como se trata, afirmando ser colírio a principal forma de tratamento. A análise dos dados permitiu concluir também que o grupo de escolaridade do ensino médio possuía a maior proporção dos entrevistados que afirmaram conhecer o glaucoma, correspondendo a 69\% destes. Conclusão: Corroborando com esses fatores, que consistem em barreiras para o diagnóstico e fidelidade do paciente ao tratamento, o presente trabalho verificou a real existência da desinformação por parte da população sobre o glaucoma, suas complicações, tratamento e métodos para o diagnóstico. Estudos encontrados na literatura observaram que pacientes com menor escolaridade apresentavam maior desconhecimento à cerca de sua afecção, informação essa verificada também neste estudo. Revelou-se insuficiência de conhecimentos em relação ao glaucoma, às formas de prevenção e de tratamento. Esse fato sugere a necessidade de ações educativas visando à divulgação de conhecimentos relativos ao glaucoma, entre os pacientes e a população em geral, como forma de prevenção da perda visual.

Descritores: Glaucoma/epidemiologia; Conhecimento; Promoção da saúde

\footnotetext{
${ }^{1}$ University Hospital Lauro Wanderley, Federal University of Paraíba (UFPB), João Pessoa/PB, Brazil.

${ }^{2}$ Cruzeiro do Sul University (UNICSUL), São Paulo/SP, Brazil.

Work conducted at the University Hospital Lauro Wanderley, João Pessoa/PB, Brazil
}

The authors declare no conflicts of interest

Received for publication: 16/7/2013 - Accepted for publication: 22/11/2012

Rev Bras Oftalmol. 2014; 73 (1): 33-6 


\section{INTRODUCTION}

$\mathbf{G}$ laucoma is the leading cause of irreversible blindness worldwide. In 2003 the Brazilian Council of Ophthalmology estimated that 900,000 individuals in Brazil had the disease and that 720,000 were probably asymptomatic and undiagnosed ${ }^{(1)}$.

The concept of glaucoma has changed over the years; it is currently defined as a chronic optic neuropathy characterised by visual field loss and optic nerve damage ${ }^{(2)}$. It is a condition that, due to its clinical characteristics and visual prognosis, requires strict adherence to treatment; the patient should undergo long-term follow-up and treatment in order to prevent blindness ${ }^{(3)}$. The main risk factors for glaucoma progression are increased intraocular pressure, age, ethnicity, family history, failure to adhere to treatment, and ignorance among the population about the disease and its visual consequences ${ }^{(4)}$.

Low adherence to treatment is common and is mainly due to lack of information about the disease and difficulties communicating with the physician and administering treatment, leading to therapeutic failure and thus glaucoma progression ${ }^{(5)}$. Authors of a study conducted in the Netherlands emphasised that disadvantaged patients with glaucoma should be educated especially with regard to the risk factors and consequences of the disease; the authors concluded that general knowledge about glaucoma and its treatment is directly related to positive treatment results. In the same study, patients of lower socioeconomic status needed more information about glaucoma, a factor which is often underestimated ${ }^{(6)}$.

Ophthalmic campaigns are mainly intended to benefit a large number of poor people and should focus on factors such as target population, location of health care services, previous screening, and possible referral of patients to specialised services, among others ${ }^{(7)}$. In addition to such campaigns, the Brazilian government has been making efforts to ensure that certain institutions provide specific tests and free drug treatment, the initial standard therapy for primary open-angle glaucoma (POAG); this promotes adherence to treatment and should help improve patient understanding of the condition ${ }^{(3)}$.

Studies that assessed patient knowledge about the disease and glaucoma treatment found that the investigated population was uninformed about their medical condition, the disease, its treatment, and the methods for diagnosing and monitoring glaucoma $^{\left({ }^{(8)}\right.}$. However, there are few studies assessing the general population's knowledge about the topic ${ }^{(9)}$. Therefore, this study sought to assess the kind of information the population receives about glaucoma and their self-assessment of their knowledge about the condition. Study subjects were volunteers participating in a glaucoma campaign held at the University Hospital Lauro Wanderley in João Pessoa/PB, Brazil.

\section{Methods}

Non-experimental, cross-sectional, descriptive, uncontrolled survey among individuals participating spontaneously in a glaucoma prevention campaign at the University Hospital Lauro Wanderley, Federal University of Paraíba (UFPB). The campaign had been previously announced in the media. The data collection instrument was a questionnaire asking subjects to selfassess their knowledge about the disease. The investigated sample was chosen randomly and included 200 participants aged above 20 years, of both sexes, who gave their Free and Informed Consent. The campaign took place on May 26, 2012, beginning at 8 am and ending at $5 \mathrm{pm}$.

\section{Have you ever had an eye examination? Do you know what glaucoma is?}

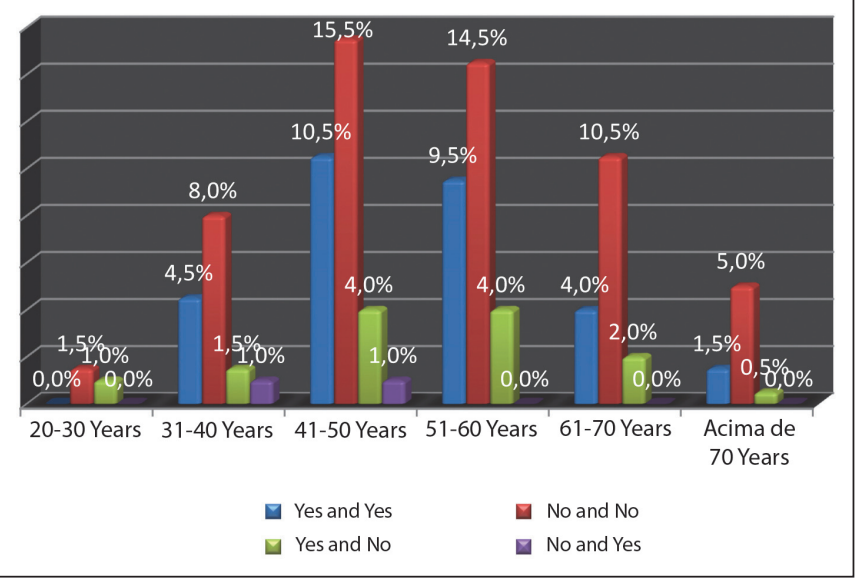

Figure 1. Assessing subjects with regard to previous eye examination and their knowledge about glaucoma

\section{ResULtS}

Of the 200 volunteers seen at the Ophthalmology Service of University Hospital Lauro Wanderley, 109 (54.5\%) were female; mean age was 51 years, ranging from 21 to 75 years.

In total, $85 \%$ of subjects reported having had a previous eye examination, most of which were women (48.5\%). Regarding education, $5 \%$ of subjects had never attended school, $22.5 \%$ had up to 4 years of schooling, $15 \%$ of had $5-8$ years of schooling, $45 \%$ had completed high school, and $14.5 \%$ had higher education.

Only $32 \%(n=64)$ of subjects said they knew the disease, of which $71.87 \%(n=46)$ stated that glaucoma is a disease that cannot be cured but can be controlled and 48.4\% $(n=31)$ had family members with glaucoma. Among subjects who knew the disease, $64 \%(n=41)$ said they knew how it is treated, stating that treatment is mainly based on eye drops. Data analysis led to the conclusion that subjects who had completed high school were more likely to know about the condition, accounting for $69 \%$ of those who knew about it.

After collecting the data, we assessed the correlation between the groups of patients that had undergone a previous eye examination and their degree of knowledge about the disease, divided into different age groups (Figure 1).

Since persons with a family history for glaucoma are more likely to develop the disease, we assessed their profile, asking them about their knowledge of the condition and stressing the importance of regular eye examinations (Figure 2).

\section{Discussion}

Glaucoma is a chronic optic neuropathy of high importance due to its harmful potential. The main factor related to glaucoma progression and failure to diagnose the disease is the lack of knowledge about the condition, as well as the little importance given to eye examination, which contributes to the lack of adherence to treatment ${ }^{(4)}$. The present study confirms the importance of these factors by showing that the population is misinformed about glaucoma, its complications, treatment, and diag- 


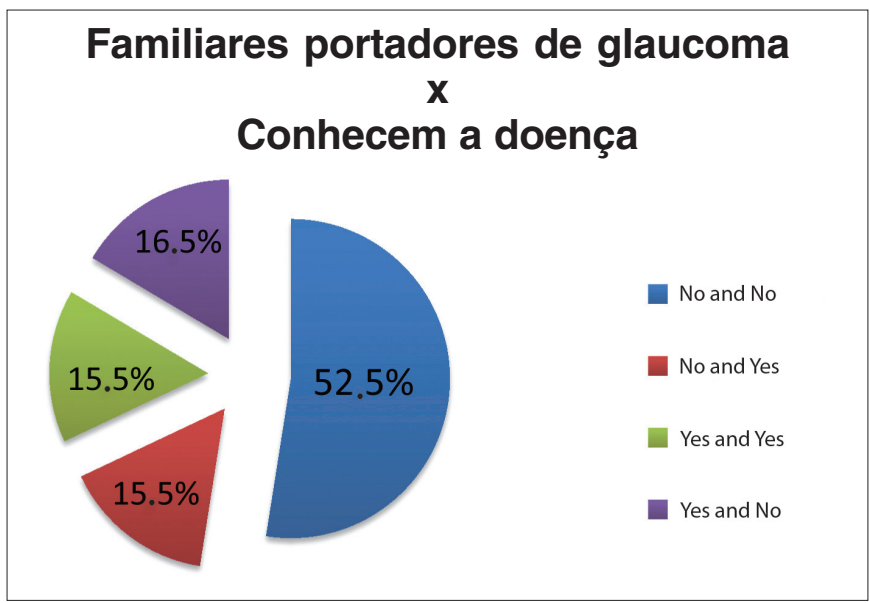

Figure 2. Patient profile with regard to family history for glaucoma and knowledge about the condition

nostic methods. Studies on patients of low educational level found that $61.1 \%$ of subjects who never attended school and $50.5 \%$ of those with up to 4 years of schooling knew little or nothing about glaucoma ${ }^{(2)}$. A lack of knowledge was also found about glaucoma, its prevention, treatment, and prognosis, stressing the need for frequent glaucoma prevention campaigns ${ }^{(2,6)}$.

Whereas glaucoma is one of the leading causes of preventable blindness in the adult population, in order to reduce the risk of blindness from glaucoma a strategy needs to be developed that encourages early diagnosis in the community. Such a strategy should involve several steps, including recognising the scale of the problem, which can be done through epidemiological studies $^{(10)}$. Is also necessary to facilitate access to primary care, bridging the gap between the population and ophthalmologists. The strategy should also aim to educate the population on glaucoma, its risk factors, treatment, and consequences.

An education plan should be routinely implemented among glaucoma patients to increase adherence to treatment and reduce the rate of disease progression ${ }^{(9,11)}$.

Whereas knowledge is a process built in the interaction between subjects, this work suggests that educating the general population can be done continuously and progressively, taking into account the concepts and meanings people attach to diseases and their treatment ${ }^{(9)}$. Using brochures or videos containing basic information about the disease and its treatment is an additional strategy which can be used to educate both the general population and glaucoma patients on the importance of early diagnosis, complications, and treatment of the disease. Such an education programme aimed at glaucoma patients is essential to prevent blindness and should be implemented not only in university hospitals, general hospitals and clinics, but also in routine ophthalmic practice.

\section{Conclusion}

Only a minority of subjects, usually those with a better educational level, showed satisfactory knowledge about glaucoma. Although a larger number of subjects had undergone previous ophthalmic examination, most subjects did not know the disease. This small representativeness points to the importance of campaigns aimed at preventing blindness from glaucoma, which are still uncommon in Brazil.

\section{CAMPAIGN TO PREVENT BLINDNESS DUE TO GLAUCOMA}

PERSONAL DATA

NAME:

AGE: SEX: $F(\quad) M(\quad)$

ADDRESS:

TEL: EDUCATION: 1-4 YEARS（） 5-8 YEARS（） HIGH SCHOOL（） SUPERIOR EDUCATION（） NEVER STUDIED（）

\section{QUESTIONÁRIO}

1) Have you ever had an eye examination? YES ( ) NO ( )

2) Do you know what glaucoma is? YES ( ) NO ( )

3) Is glaucoma a transmittable disease? YES ( ) NO ( )

4) Do you know how glaucoma is treated? YES ( ) NO ( ) EYE GLASSES ( ) EYE DROPS ( ) SURGERY ( )

5) Can glaucoma be cured? YES ( ) NO ( ) Can it be controlled? YES ( ) NO ( )

6) Você já fez alguma cirurgia ocular? YES ( ) NO ( )

7) Have you ever had an eye surgery? YES ( ) NO ( )

8) Do you have a family member with glaucoma? YES ( ) NO ( ) 


\section{ANNEX 2}

\section{FREE AND INFORMED CONSENT}

Dear Sir/Madam,

This study is called Knowledge about glaucoma and epidemiological profile of subjects seen in a campaign conducted at

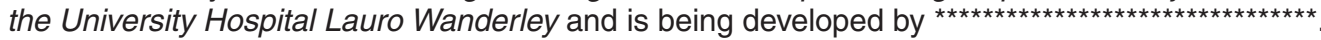

Its overall aim is to assess the general knowledge of the population about glaucoma and to determine the epidemiological profile of study participants (information such as sex, age, education).

We ask you to cooperate by responding to our questionnaire (a specific questionnaire containing simple questions about your knowledge of glaucoma, which was developed by a medical researcher and will be applied by researchers) and we request your authorisation to present the results of this study in events related to health care and to publish them a scientific journal. When the results are published, your name will be kept secret. This study entails no foreseeable risks to your health.

Your participation in the study is voluntary; therefore, you not required to provide information and/or to support the activities requested by the researcher. If you decide not to participate in the study or if you decide to drop out of it at any moment you will not be penalised in any way nor will there be any change in the care you receive in this institution.

The researchers will be at your disposal for any clarification you might need at any stage of this study.

Given the above, I declare that I was duly informed and that I consent to participate in this study. I also consent with the publication of its results.

I am aware that I will receive a copy of this document.

Subject's or legal guardian's signature

Contact with researcher in charge:

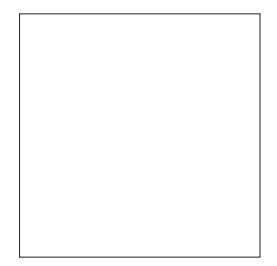

Finger print

If you need further information about this study, please call

Sincerely,

Researcher's signature

\section{REFERÊNCIAS}

1. Silva LR, Paula JS, Rocha EM, Rodrigues ML. Fatores relacionados à fidelidade ao tratamento do glaucoma: opiniões de pacientes de um hospital universitário. Arq Bras Oftalmol. 2010;73( 2):116-9.

2. Silva MJ,Temporini ER, Neustein I, Araujo ME. Conhecimentos sobre prevenção e tratamento de glaucoma entre pacientes de unidade hospitalar. Arq Bras Oftalmol. 2004;67(5):785-90.

3. Paula JS, Ramos Filho JA, Cecchetti DF, Nagatsuyu DT, Rodrigues ML, Rocha EM. Medical decision, persistence of initial treatment, and glaucoma progression in a Brazilian reference hospital. Arq Bras Oftalmol. 2010;73(2):141-5.

4. Van Buskirk EM, Cioffi GA. Glaucomatous optic neuropathy. Am J Ophthalmol. 1992;113(4):447-52. Review.

5. Amaral A, Leitão P, Pinto L, Ferreira AS, Silva JP, Silva J, Reina M. Avaliação do conhecimento, adesão terapêutica e repercussão de uma sessão educativa sobre o glaucoma numa população de doentes seguidos na consulta de especialidade num hospital central. Oftalmologia. 2010;34(Jul/Set):429- 44.
6. Hoevenaars JG, Schouten JS, van den Borne B, Beckers HJ, Webers CA. Socioeconomic differences in glaucoma patients' knowledge, need for information and expectations of treatments. Acta Ophthalmol Scand. 2006;84(1):84-91. Comment in Acta Ophthalmol. 2009;87(4):468-9; author reply 469-71.

7. Araújo AL, Zucchetto NM,Fortes Filho JB. Campanhas de promoção de saúde ocular: experiência do Hospital Banco de Olhos de Porto Alegre. Rev Bras Oftalmol. 2007;66(4):231-5.

8. Costa VP, Vasconcelos JP, Pelegrino M, José NK. O que os pacientes sabem sobre glaucoma? Arq Bras Oftalmol. 1995;58(1):36-41.

9. Leal BC, Medeiros FA, Oliveira BFT, Pinheiro, Susanna Jr. R, KaraJosé N. Fatores associados ao conhecimento de glaucoma numa população de hospital terciário. Rev Bras Oftalmol. 2001;60(8):556-62.

10. Sakata K, Sakata LM, Sakata VM, Santini C, Hopker LM, Bernardes $\mathrm{R}$, et al. Prevalence of glaucoma in a South brazilian population: Projeto Glaucoma. Invest Ophthalmol Vis Sci. 2007;48(11):4974-9.

11. Leite MT, Sakata LM, Medeiros FA. Managing glaucoma in developing countries. Arq Bras Oftalmol. 2011;74(2):83-4. 